\title{
Determinants of Turnover Tax (ToT) Tax Collection Effectives in Ethiopia: The Case Hosanna Town
}

\author{
Dereje Lemma Lalisho, Muluget Abuye \\ Department of Accounting and Finance, College of Business and Economics, Wachemo University, Hosanna, Ethiopia \\ Email address: \\ derelema12@gmail.com (D. L. Lalisho),2003.mulugeta@gmail.com (M. Abuye) \\ To cite this article: \\ Dereje Lemma Lalisho, Muluget Abuye. Determinants of Turnover Tax (ToT) Tax Collection Effectives in Ethiopia: The Case Hosanna \\ Town. American Journal of Theoretical and Applied Business. Vol. 6, No. 3, 2020, pp. 28-36. doi: 10.11648/j.ajtab.20200603.13
}

Received: June 22, 2020; Accepted: July 24, 2020; Published: September 19, 2020

\begin{abstract}
This paper aims to explore that factor influencing the effectiveness of Turnover tax collection in Hosanna Town. The study organized factors into four categories: Tax- administration related, Tax officers-related, Taxpayers-related and Tax systems related factors. The study used an explanatory approach, whereby data from 276 taxpayers' for three sub-cities in Hosanna Town were collected using administers the questions. The questionnaire had 38 statements representing factors and 12 statements representing the Turnover tax revenue collection effectiveness. The collected data were analyzed using both descriptive and inferential statistics. In the case of descriptive statistics, the study used frequency, percentage, mean and standard deviation. For the inferential statistics, the study used multiple regression analysis. The study findings showed that there were eight main critical factors turnover tax effectiveness. The results showed that turnover tax rate, mode of payment, Government policy formulation and services to taxpayers, Taxpayers knowledge of obligations and rights are factors that positively significantly effective on turnover tax revenue. However, punishment by tax office, detection capabilities of tax offices, education and advice from tax office were not significantly at 5\% significance effective on turnover tax revenue. Despite the contributions of this study, there are some limitations which need to be acknowledged. First, data were collected from taxpayers only. Secondly, only 12 statements for factor were used. Thirdly, the study has used only primary data. Last, perceptual measures of turnover tax collection effectiveness. The authors consider that if other approaches were used, they could have reached different conclusions. From a practical perspective, revenue authority may be relying heaviling on taxpayers, as well as regulations, directives and proclamation, for turnover tax collection effectives. The study shows that mode of payment, taxpayer right and obligations on proclamation and tax policy on turnover tax are critical factors too. However, the study also has practical implications for local (Town) governments, revenue authority, turnover tax collection and taxpayers at large. This paper extends prior research in the area of turnover tax collection and is the first paper to use four categories of factors to analyze the influencing of turnover tax collection effectiveness, taking into consideration both tax authorities and taxpayers. It is used the model, which helped to generate variables with multiple prior theories (i.e. theoretical triangulation). Hence, new theories were combined with old theories to produce findings which take into consideration the context of the country.
\end{abstract}

Keywords: Tax Compliance, Turnover Tax, Taxpayers', Ethiopia

\section{Introduction}

The government collects revenue from tax to ensure its funding and to finance basic infrastructures in the nation; however, for the taxpayer also important to be treated in way is procedurally fair [26]. Tax administration, therefore, covers a wide area of the study, encompassing aspects such as registration of taxpayers, assessments, returns processing, collection, and audits [30].
Ethiopia introduced turnover tax in the year 2002 as a replacement of sales tax like that of VAT. Turnover tax (ToT) is also a principal source of revenue for Ethiopian government specifically for Hosanna Town Revenue authority (Proclamation No. 308/2002). Turnover tax (ToT) is a simple tax on the gross income of tax that would be on goods sold and services rendered by persons not registered for Value Added Tax Person not Registered for VAT" means a person who, according to Article 16 and 17 of the Value 
Added Tax Proclamation, is not registered by reason of his annual turnover being below Birr 500,000 or threshold set by the Minister; or by reason of not having applied for voluntary registration.

Turnover tax is a tax that targets what is most commonly known in Ethiopia as the informal sector. The informal sector comprises of the micro and the small enterprises most of which are not well organized, they use labour intensive technology and most of them are unregistered. Turnover tax targets traders, artisans and others working in market stalls, in residential houses or in open places [29].

Some of the problems regarding the informal sector that exist under the income tax are likely to remain so, particularly those involving cash transactions made in the informal economy or with the explicit intent of evading taxation. However, as the costs of compliance reduce and the perceived fairness of the tax system increases, some of the hostilities to the turnover tax system may decline. Businesses that are in non-compliance because they perceive the present system as unfair or illegitimate may choose to comply. Research has confirmed the intuitive relationship between higher marginal tax rates and higher rates of evasion. Lower rates, all other things being equal, imply lower evasion because the benefits from evasion decline while the costs of evasion remain comparable [34].

Small businesses are viewed as more likely to evade taxes since the owner, and beneficiary of tax evasion, is more likely to also be responsible for keeping the books and filing the tax returns. Those small business persons that are inclined to cheat on their sales tax are probably already cheating on their income tax and would be inclined to do so under any tax system. Further, the economic importance of small firms in the retail sector is usually grossly overstated [12].

The taxation of SMEs faces several major policy challenges. The first one concerns compliance costs of taxation. Existing empirical evidence clearly indicates that small and medium sized businesses are affected disproportionately by these costs: when scaled by sales or assets, the compliance costs of SMEs are higher than for large businesses. Given that small start-ups and research oriented SMEs are generally considered as important factors for economic growth, tax compliance cost may slow down the economy. At least two policy responses to the problem of compliance costs are conceivable. Governments could try to generally simplify tax administration for businesses. At the same time, special responses targeted at SMEs are conceivable. For example, a widely observed measure to reduce the cost for small businesses are exemption thresholds under value added taxation [41].

\subsection{Statement of the Problem}

Taxation can have important effects on many parts of the economy, including impacts on firm creation and on the development of small and medium-sized enterprises (SMEs). Developing an environment conducive to SME growth whilst ensuring tax compliance is a challenge all countries face. Weichenrieder [41] posits that the taxation of SMEs faces several major policy challenges that include compliance costs of taxation, revenue cost, tax evasion, incorporation and definition of SMEs. Chilipunde and Shakantu [6] further argue that the SMEs management have inadequate training and business skills and have a high prevalence of unethical conduct. Forum on Tax Administration (2009) argues that it is critical that a very high degree of compliance is achieved for the proper reporting of income and payment of associated taxes by all taxpayers. Among many SMEs this compliance is eroded by deliberate withholding of tax related information. This leads to difficulties in the realization of the incomes from turnover tax.

In Kenya, Memba, Gakure and Karanja [25] posit that the informal sector is not only a provider of goods and services but also a driver in promoting competition, innovation and enhancing the enterprise culture which is necessary for private sector development and industrialization. They further argue that it is growingly economically important and should effectively respond to challenges of creating productive and sustainable employment opportunities, promoting economic growth and poverty eradication in the country. On the contrary to expectation, Waweru [40] found collecting turnover tax from these businesses both a challenge and with dwindling revenues.

The nature of the challenges posed by non-compliance, and the search for simple tax regimes suitable for small enterprises, differs substantially across countries. Kringi, Wanjala, Nyamunga, Okello, Pambah, \& Nyakang o, [22] acknowledge that like many other developing countries, Kenya faces challenges in taxing income derived from agriculture and the informal sector. However, an empirical study by Muriithi and Moyi [27] suggested that tax reforms in Kenya under the Tax Modernization Program have led to improved productivity of direct taxes. The findings by Waweru [40] showed that whereas tax revenues in Kenya were on the rise, the revenues from turnover tax were getting slimmer. A research gap exists here for whereas Kiringi et al [22] agree there are challenges facing tax collection in developing countries, Muriithi and Moyi [27] agree that the Kenyan government has come up with reforms to address the challenges resulting in a general increase in tax incomes. However, according to Waweru [40] the turnover tax is not raking in the expected increment in collection. The question that arises is whether the performance in the turnover tax collection is addressing the real challenges on the ground? Therefore this study will answer the questions: what factors affect the collection of turnover tax? And, what ways will be used to overcome the challenges of Turnover tax in Hosanna town? Hosanna town revenue collection is among the pioneer Turn over tax revenue in the South Nation Nationality People Region (SNNPR) collecting revenue the Hosanna Town, which also experiences considerable problem of Turn over tax revenue collection. This study is aimed at challenges affecting collection of turn over tax (ToT) in Hosanna Town

According to annual report of 2017/2018, the revenue authority of Hosanna Town the annual planned revenue assume to collect from indirect tax around $\mathrm{Br} 100,546$ but the 
actual amount which collected is around $\mathrm{Br} 45,000$. It has significant difference of $\mathrm{Br} 55,546$ it is very surprise issue which requires research to determine and measure the responsible factors for the existence of this deviation. This indicates that even if the tax authority strives to collect high amount of revenue it collect only $78 \%$ of total budgeted. Turnover tax collection procedures had its own contribution for the existence of this disparity between the amount of tax revenue planned to collect and actually collected by revenue office. Hosanna town is the capital city of Hadiya zone in South region the experience ineffectiveness in turnover tax collection (South revenue authority, 2017/2018). The numbers of empirical evidence which focus on this area were limited and no prior studies had been conducted on this tax and research which conducted in Kenya 2013 indicates that the challenges which affects collection of turnover tax collection on SMEs is the mode of payment is time consuming and tedious [41]. Although such studies have contributed substantially to the literature on turnover tax, their findings may not be applicable to other countries like Ethiopia, due to differences in tax system (principles, cultural, economic and legal environments.

To the best of the researcher's knowledge, there exists no previous research work in Ethiopia concerning determinants the turnover tax collection. Therefore, this study is particularly intended to examine the determinants of Turnover tax collection in Hosanna Town. Such a study is hopefully expected to fill the gap in literature by scrutinizing the determinants of Turnover tax collection performance in Hosanna Town.

\subsection{Prior Research and Hypotheses Development}

In line with the broad purpose statements, the following hypotheses were formulated for investigation. Hypotheses of the study stand on the theories related to factors for collection of turnover tax collection. The results from the literature review which are used to establish expectations for the relationship of various variables which are affecting turnover tax revenue collection effectiveness. Hence, based on the objective of the study, eight hypotheses were hypothesized as follows.

H1. There is a positively significantly relationship between mode of payment and effectiveness of collection of turnover tax revenue.

SME returns represent the bulk of forms received and processed. These returns, unlike large taxpayers' returns, have a disproportionate number of inconsistencies, missing information, and unintentional errors. High benefits can be realized where there is return simplification, plain language instructions, banks payment processing, reductions in filing and payment frequency, and e-filing and e-payment acceptance [20]. The study agrees with the findings of DAC [8] and Siyimu [41]. Mode of payment was a major problem for the taxation of small businesses for the cost of turnover tax payment was high for them, their incomes seasonal and unstable and had limited use of banks.

$\mathrm{H} 2$ : There is a positively significantly relationship between tax payers knowledge of obligations and rights and effectiveness of collection of turnover tax revenue.

Tax education and knowledge about tax laws plays a major role in determining taxpayers' compliance behavior and to ensure tax collection effectiveness [17]. Concerning tax payers knowledge of obligations and rights, the SMEs most strongly felt that, not only did the tax office not value feedback about the way the tax system was, but also strongly felt that they did not understand their obligations. This greatly affected turnover tax collection. On the contrary, the fact that the tax office did value feedback about the way the tax system was run did not greatly affected turnover tax collection. The findings are in agreement with the findings of Ojeka [28] who found that the manner in which turnover tax was collected encouraged extortion for the taxpayers were ignorant of their rights and were not involved in formulation of taxation policies.

H3: There is a positively significantly relationship between turnover tax rate and effectiveness of collection of turnover tax revenue.

Concerning turnover tax rate, it was found to be prohibitive and higher than profit margins therefore affecting turnover tax collections. The formula for calculating the tax is not difficult and it did not affect tax collection. The findings agree with Freeman, Ellis and Allison [11] and Ahmet [1]. Freeman, Ellis and Allison [11] found that SMEs in the rural Kenya identified taxation as too high. Ahmet [1] had found that small businesses in Bulgaria had found tax as the most significant barrier to their investments.

$\mathrm{H} 4$ : There is a positively significantly relationship between Government policy formulation and quality of services to taxpayers affect turnover tax collection effectiveness.

The SMEs indicated that the government failure to involve taxpayers when formulating tax policies affected turnover tax collection. Lack of visible improvements in government services and poor political goodwill towards turnover tax also affected turnover tax collection. The findings agree with those of DAC [8] who found that the taxpayers perceived the government as a consistent plunderer of tax revenues.

H5: There is a positively significantly relationship between penalties and fines impose on taxpayers and effectiveness of turnover tax collection.

Tax collection effectives were significantly increased with higher penalties but not with audit probability in the study by Friedland, Maital, \& Rutenberg [15]. In contrast, other studies have shown that fines and penalties are not related at all to effectiveness; even though they were able to confirm that the probability of being audited is related to compliance [49].

H6: There is a negatively significantly relationship between education and advice from revenue authority on taxpayers and effectiveness of turnover tax collection.

Research conducted a study that sought to find out an assessment of challenges of administrating turnover tax collection a case study of Kenya revenue authority and came up with effective communicative and support to taxpayers (the measured by, satellite offices and help lines, Broad casts 
and seminars, Billboards, guides and bulletins) were found not significantly in influencing the effectiveness of the measures, applied by Kenya revenue authority to increase tax turnover [41].

H7: There is a positively significantly relationship between detection capabilities of revenue authority on taxpayers and effectiveness of turnover tax collection.

Most taxpayer's report their tax liability more accurately if they believe that the tax administration has the capacity to detect any unreported liabilities and that heavy penalty may be applied when they are detected [2] and were found significantly in influencing the effectiveness of the measures, applied by Kenya revenue authority to increase tax turnover [41].

H8: There is a positively significantly relationship between punishment by revenue authority impose on taxpayers and effectiveness of turnover tax collection.

Punishment by revenue authority was identified as significant in influencing the effectiveness of the measures applied by Kenya revenue authority to increase tax turnover. [41].

\section{Research Design and Methodology}

\subsection{Research Design}

This study is a survey research type. Quantitative approach research design enables current description of the phenomena being studied. Quantitative research is a means for testing objective theories by examining the relationship among variables [9]. This study required the careful analysis of the current challenges facing the implementation of the turnover tax in Ethiopia of South region in Hosanna town. The quantitative research design therefore provided the mechanisms to achieve this requirement.

\subsection{Target Population}

The target population of this study is composed of category" taxpayers and a person who sells goods and services have registered and the obligation to collect the Turnover Tax from the buyer and transfer it to the Revenue Authority that located in Hosanna town. Therefore, the registered category "C" taxpayers are located within this region made up the population of this study. There are 950 registered TOT taxpayers in Hosanna town of South of Ethiopia region.

\subsection{Sample Size and Sample Techniques}

According to Cochran's [10] sample size, determination formula is employed for this study. The numbers of category "C" (Small micro enterprise) are taxpayers, total the study size comprise of 984 taxpayers and it assume that the sample should have $95 \%$ reliability and a sampling error of $5 \%$ or 0.05. Using the following scientific formula we can determine the sample size of the study.

$\mathrm{n}_{0}=\frac{z_{\alpha / 2}^{2} \mathrm{pq}}{d^{2}}$ (To determine the sample size in estimating the mean or the proportion of finite population).

Where $\mathrm{z}=$ value for selected alpha level of 0.025 in each tail (for 95\% degree of confidence) $=1.96$

$(p)(q)=$ estimate of variance $=0.25$

$\mathrm{D}=$ acceptable margin of error for proportion being estimated $5 \%=0.05$

$$
\mathrm{n}_{0}=\frac{(1.96)^{2} * 0.5 * 0.5}{0.05^{2}}=384
$$

Therefore since the initial sample size is greater than $5 \%$ of the total population $(5 \% * 984=49.2)$, Cochran's [10] correction formula will be used to calculate the final sample size.

These calculations are as follows:

Therefore, the maximum size sample is-

Representative sample for proportions in large populations Cochran [10] to make

$$
\mathrm{N}=\frac{n_{o}}{1+\frac{n_{o}}{N}}
$$

Whereas,

$\mathrm{n}$ - The sample size

$\mathrm{N}$ - The population size

e - The acceptable sampling error

To get sample size, the target population size is 984 ; the acceptable sampling error is $95 \%$ of confidence interval,

$$
\text { So } \mathrm{n}==\frac{n_{o}}{1+\frac{n_{o}}{N}}
$$

$\mathrm{n}=\frac{384}{1+\frac{384}{984}} \mathrm{n}=\frac{384}{1.3902439}, \mathrm{n}=276$, total sample size of survey of taxpayers

Moreover, sample respondents were selected proportion of the sample size from each sub city as follows:

Hence, proportion of the sample size to find the number of respondents in each category is determined by dividing the sample size to target population taken. The reason for using proportionate sample is to give equal chance for all respondents. To determine sample size from each stratum, sample size determination formula is:

Sample size proportion $\left(\mathrm{s}_{\mathrm{n}}\right)=\left(\frac{\text { sample size }(\mathrm{Ps})}{\text { target population }(\mathrm{P})}\right) * \mathrm{~N}$ and to get sample size of sub city

$\mathrm{S}_{\mathrm{n}}=276^{*}\left(\frac{P s}{P}\right)$, whereas $\mathrm{S}_{\mathrm{n}}=$ sample size of sub city, $\mathrm{P}_{\mathrm{s}}=$ the sub city population, $\mathrm{P}=$ the city population, and 276 the sample size of the study (Israel [27] and Cochran [10]). Based on this formula sample size each stratum provided table below. 
Table 1. Proportionate sample size from each stratum.

\begin{tabular}{lllll}
\hline \multirow{2}{*}{ No } & Sub-city name & Sub-city population & Description & Proportionate of sample size from stratum $\mathbf{S}_{\mathbf{n}}\left(\mathbf{P}_{\mathbf{s}} \div \mathbf{P}\right) * \mathbf{N}$ \\
\cline { 4 - 5 } & & & Taxpayers \\
\hline 1 & Sechi duna & 458 & RTOT $(458)$, & 128 \\
2 & Gofare mada & 420 & RTOT $(420)$, & 118 \\
3 & Addis ketem & 106 & RTOT $(106)$ & 30 \\
4 & Hosanna & 984 & Total & 276 \\
\hline
\end{tabular}

Source: Adopted from Hosanna Revenue Authority, 2017/2018.

NB: Registered to collect the turnover tax.

\subsection{Method of Data Analysis and Presentation}

The method that were used descriptive and Econometrics methods are employed to analyze the data in the present research.

\section{Econometrics Method}

Even though, there is no compelling reason to choose ordinal ordered regression model over the probit, in practice many researchers choose the ordinal model because of its comparative mathematical simplicity. Accordingly, this research has applied the logit model; then the dependent and independent variables are presented as follows:

a) Dependent variable (ordinal continuous by taking the average value by compute the variable by SPSS) $=$ Turnover tax revenue

b) The independent variable=the variables affecting the turnover tax revenue collection.

The ordinal ordered regression model was specified as follows:

$$
\begin{array}{r}
\mathrm{Yi}=\alpha+\beta 1 \mathrm{X} 1+\beta 2 \mathrm{X} 2+\beta 3 \mathrm{X} 3+\beta 4 \mathrm{X} 4+\beta 5 \mathrm{X} 5+\beta 6 \mathrm{X} 6+\beta 7 \mathrm{X} 7+ \\
\beta 8 \mathrm{X} 8+\beta 9 \mathrm{X} 9+\beta 10 \mathrm{X} 10+\beta 11 \mathrm{X} 11+\mathrm{e} . .
\end{array}
$$

Where,

$\mathrm{Y} i=$ Turnover tax; $\alpha=$ Constant; $\beta \mathrm{i}=$ Vector of unknown parameters; $\mathrm{X} 1=$ turnover tax rate; $\mathrm{X} 2=$ mode of payment;
$\mathrm{X} 3$ =taxpayers knowledge of obligation and rights; $\mathrm{X} 4=$ Government policy formulation and services to taxpayers; $\mathrm{X} 5=$ education and advice from tax office; $\mathrm{X} 6=$ Detection capabilities of tax office; X7=Punishment by tax office and $\mathrm{e}=$ error term.

\section{Research Findings and Discussions}

\subsection{Introduction}

This chapter presents the data analysis, presentation and interpretation of findings on the data collected from HRA respondents. The study focused on significance of eight independent variables under one dependent in influencing the effectiveness of Hosanna Revenue Authority Domestic (Sub city) Taxes Department in efforts to improve turnover tax collection. The study was focused on the Hosanna Town, both the commercial capital and seat of government of Hadiya Zone. The main objective of the study was to evaluate extent to which taxpayer factors influence tax compliance levels (turnover tax collection). The study sampled one hundred and ninety four respondents (194) HRA Domestic Taxes (SMEs, (Small and Micro taxpayer) staff respondents within Hosanna Town) and the data interpreted as per the research questions.

$$
\begin{aligned}
& \text {. *(10 variables, } 194 \text { observations pasted into data editor) } \\
& \text { - regress tot mop tpor gp totp tr pra dcra eara }
\end{aligned}
$$

\begin{tabular}{r|crc} 
Source & SS & df & MS \\
\hline Mode1 & 131.832975 & 8 & 16.4791219 \\
Residua1 & 18.1515612 & 185 & .098116547 \\
\hline Tota1 & 149.984536 & 193 & .777121949
\end{tabular}

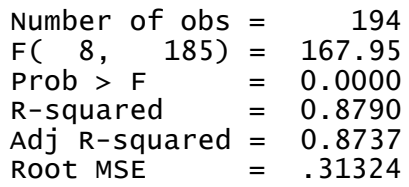

\begin{tabular}{r|rrrrrr}
\hline tot & Coef. & Std. Err. & $\mathrm{t}$ & $\mathrm{P}>|\mathrm{t}|$ & [95\% Conf. Interva1] \\
\hline mop & .5513066 & .1787083 & 3.08 & 0.002 & .1987383 & .9038748 \\
tpor & -.6839535 & .1745278 & -3.92 & 0.000 & -1.028274 & -.3396329 \\
gp & -.6237838 & .0717182 & -8.70 & 0.000 & -.7652746 & -.4822931 \\
totp & -10.19463 & 1.149179 & -8.87 & 0.000 & -12.46181 & -7.927449 \\
tr & 1.122543 & .0929824 & 12.07 & 0.000 & .9391009 & 1.305985 \\
pra & -.0341217 & .225297 & -0.15 & 0.880 & -.4786034 & .41036 \\
dcra & .0214259 & .2091598 & 0.10 & 0.919 & -.3912192 & .434071 \\
eara & -.1172728 & .1822536 & -0.64 & 0.521 & -.4768354 & .2422898 \\
cons & -.3599782 & .1398423 & -2.57 & 0.011 & -.6358688 & -.0840876 \\
\hline
\end{tabular}

Figure 1. Output of STAT.

\subsection{Regression Analysis}

The choice of the type of regression to use is determined by the type of measurement of the dependent variable. In this case the dependent variable is ordinal hence the choice of ordinal regression. Ordinal regression is preferred to linear regression as it is more stable and most suitable for the data. 
A test was undertaken to determine whether the model improves our ability to predict the outcome. We do this by comparing a model without any explanatory variables (the baseline or "Intercept only" model) against the model with all the explanatory variables (the "Final" model - this would normally have several independent variables). The significant chi-square statistic $(p<0.0001)$ indicates that the final model gives a significant improvement over the baseline interceptonly mode.

Adj $R$ squared (the coefficient of determination) summarizes the proportion of variance in the dependent that can be accounted for by the independent variables. R-squared $(\mathrm{R}=0.8737$ or $87.37 \%$ ) indicates that the eight independent variables explain $87.37 \%$ proportion of the variation in the measures HRA (Hosanna Revenue authority) has undertaken to increase the tax turnover yield.

\subsection{Interpretation}

The results of this study were providing evidence that various determinants found by previous researchers.

Mode of payment

SME returns represent the bulk of forms received and processed. These returns, unlike large taxpayers' returns, have a disproportionate number of inconsistencies, missing information, and unintentional errors. High benefits can be realized where there is return simplification, plain language instructions, banks payment processing, reductions in filing and payment frequency, and e-filing and e-payment acceptance [20]. The study agrees with the findings of DAC [8] and Siyimu [41]. Mode of payment was a major problem for the taxation of small businesses for the cost of turnover tax payment was high for them, their incomes seasonal and unstable and had limited use of banks.

In this study research found that significant value of the mode of payment is acted 0.000 at $5 \%$. This imply that the mode of payment affect turnover tax collection and the coefficient of the regression is positive $(\beta=.5513066)$, the hypothesis is accepted. As far as high suitable or using technology the mode of payment of the turnover tax was to be time consuming and tedious. It is also concluded that turnover taxpayer's encountered problems while filing turnover tax returns.

Tax Payers Knowledge of Obligations and Rights

Tax education and knowledge about tax laws plays a major role in determining taxpayers' compliance behavior and to ensure tax collection effectiveness [17]. Concerning tax payers knowledge of obligations and rights, the SMEs most strongly felt that, not only did the tax office not value feedback about the way the tax system was, but also strongly felt that they did not understand their obligations. This greatly affected turnover tax collection. On the contrary, the fact that the tax office did value feedback about the way the tax system was run did not greatly affected turnover tax collection. The findings are in agreement with the findings of Ojeka [28] who found that the manner in which turnover tax was collected encouraged extortion for the taxpayers were ignorant of their rights and were not involved in formulation of taxation policies.

In this study researcher found that significantly value of the taxpayer's knowledge of obligations and rights is acted 0.000 at $5 \%$. This imply that the taxpayers knowledge of obligations and rights affect turnover tax collection and the coefficient of the regression is negative $\beta=.-6839535$, the hypothesis is rejected.

\section{Turnover tax rate}

In this study researcher found that significantly value of the turnover tax rate is acted 0.000 at $5 \%$. This imply that the concerning turnover tax affect turnover tax collection and the coefficient of the regression is positive $(\beta=1.12254$, the hypothesis is Accepted.) Concerning turnover tax rate, it was found to be prohibitive and higher than profit margins therefore affecting turnover tax collection. Previous study (for example, Freeman, Ellias and Allsion [11] and Ahmet [1] found that SMEs in the rural Kenya identified taxation (turnover tax rate) as too high and the most significant barrier to their investments, but in Ethiopia (in this research) found that SMEs in the rural and Urban turnover tax rate as too low. i.e. rate is $2 \%$ and $10 \%$ ) as the most insignificantly barrier to their investments and taxpayers at large.

Government Policy Formulation and Services to Taxpayers

The SMEs indicated that the government failure to involve taxpayers when formulating tax policies affected turnover tax collection. Lack of visible improvements in government services and poor political goodwill towards turnover tax also affected turnover tax collection. The findings agree with those of DAC [8] who found that the taxpayers perceived the government as a consistent plunderer of tax revenues but the findings of this research was contradicting, this might be the Hosanna town revenue failure to involve taxpayers when formulating tax polices affect turnover tax collection and many problems had faced on implementation on turnover tax polices/proclamation No. 308/2008) and lack of visible improvements in government services and poor political good will towards turnover tax also affected turnover tax collection.

In this study researcher found that significant value of the government policy formulation and services to taxpayers is acted 0.00 at $5 \%$. This imply that the Government policy formulation and services affected turnover tax collection and the coefficient of the regression is negative $(\beta=.6237838)$, the hypothesis is rejected.

Turnover tax penalties and fines on taxpayers

The research studies by fisher in 1992 showed that penalties have a larger impact on compliance than the probabilities of being audited and larger compliance mean the tax payers report full tax liability and pay on time by fearing penalties and fines this leads to effectiveness in tax collection. In contrast, other studies have shown that fines and penalties are not related at all to compliance; even though they were able to confirm that the probability of being audited is related to compliance [49]. It showed tax penalties and fines had not impact on tax collection effectiveness. This study found that tax penalties and fines on taxpayers found 
that significantly affect turnover tax collection compliance and the coefficient of the regression is negative $(\beta=-$ 10.19463), the hypothesis rejected. This study supports the second argument. As it indicated in the above even if the relation is negative it had significant on collection effectives.

Education and advice from tax office

Tax payers cannot comply if they are not aware and don't understand the tax laws and procedures: so continuous education is a critical component of such a programmed. Therefore, constant effort must be made to simply the law and procedures to make it easier and less expensive for taxpayers to comply with their obligations. However, as this study demonstrates, facilitation measures not accompanied by requisite measures that enhance high probability of detection and punishment of willful offenders will invariably have no impact on the increase in collection of turnover tax. James, 2018. It showed tax education and advice from the tax office had not impact on turnover tax collection effectiveness. This study supports this argument. As it indicates in the above regression table even if the relation is negative if had insignificant impact on turnover tax collection effectiveness.

Detection capabilities of tax office

The survey result on 2004 by Barrera and Ramachandran disclose that if the tax administration had ability and had a capacity for coverage of audit document and heavy penalty may be applied when they are detected, taxpayer's report their tax liabilities more accurately. It means tax audit helps to whether taxpayers report their tax liability based on tax regulation. According to Ebrill and others (2010), if the tax audit and verification procedure is very weak, the taxpayers encourage reporting their tax liability by understating less than which was expected from them. Tax audit strength can be measured by various variables like number of audit staff, well defined auditing manual and documents, enhancing auditor's competence, including all taxpayers in audit sample without ignoring previously audited taxpayers. On enforcement, the study found out that there was limited detection capability, sanctions and punishment for failure to comply. The analysis indicates a more focused investment by Kenya Revenue authority in reviewing powers and procedures, detection of non-compliant taxpayers and punishing of those who willfully comply has the potential of increasing the TOT revenue base. James, 2018. This study supports this argument. As it indicates in the above regression table even if the relation is negative if had insignificant impact on turnover tax collection effectiveness.

\section{Conclusions}

To conclude, it can be argued that turnover tax collection effectiveness was affected by different factors. These factors can be grouped into tax administration, tax officers, taxpayer and tax system (Proclamation). Specifically, it can be conclude that some factors had a strong positive significantly relationship with turnover tax collection effectiveness, namely, mode of payment, turnover tax rate and Government policy formulation and services to taxpayers, taxpayers knowledge of obligations and right, turnover tax penalties and fine were a negatively significantly relationship with Turnover tax collection effectiveness.

The challenges facing turnover tax collection in Ethiopia include the mode of payment of the turnover tax was found to be time consuming and tedious. It is also concluded that turnover taxpayers encountered problems when filing turnover tax returns. The SMEs also indicated that they did not understand their obligations. Further, the tax office did not value feedback about the way the tax system was run.

The turnover tax was found to be prohibitive and higher than profit margins. Tax officers contributed to the turnover tax collection problem by accepting bribes when offered to reduce tax liability or by demanding for bribes when they visited. The government also failed to involve taxpayers when formulating tax policies and there were no visible improvements in government services. In addition there was poor political goodwill towards turnover tax.

To mitigate against these challenges the suggested remedies that could improve turnover tax collection included: putting in place tough laws to check evaders, frequent taxpayer education and sensitization, putting in place mechanisms to address public misconceptions or inaccuracies and providing information in a customer-focused way to reduce error.

\section{Recommendations}

\subsection{Policy Level}

The government must step up its focus on improvement of the inefficient supply chain and promotion of formal associations of primary producers so as to integrate small farmers while creating possibilities of economies of scale. The implementation of these proposals must be considered alongside measures to improve the business climate through the creation of small operator retail markets, better infrastructure and reducing the number of unregistered informal market intermediaries. Increasing opportunities for reduced dependence on disproportionately high cash transactions through incentives for use of MPESA is likely to enhance opportunities for third-party verification of income and availability of basic accounting ledgers. Automation of payments in the largely informal transport sector such as the Beba Pay Initiative in the transport sector will go a long way in providing for identification of income earners and tracing of records on incomes.

\subsection{At a tax Administration Level}

HRA must design a taxpayer compliance programmed for the micro and small businesses that allows incorporation of all salient aspects of implementation. The program should elaborate on the number of taxpayers, nature of entities, total tax contribution, number of persons employed. The program should also identify the specific risks on a sector by sector basis and describe how HRA intends to respond to these issues and risks. The program should provide establish 
effective monitoring and other feedback mechanisms that ensures that the planned activities are carried out. This would complete the implementation cycle as it provides opportunities to shift strategy towards improving collection of TOT where problems are identified. Strategies on implementation on TOT must take into consideration those in the informal sector earning wages above the minimum threshold and bring them into the tax net by requiring their employers to submit Pay As You Earn (PAYE) taxes.

All taxpayers must be encouraged to file a return whether or not their tax payment is final. This is an essential part of the data collection that also ensures uniform treatment for all citizens gainfully employed or conducting business in the formal or informal sector. This measure will aid transition to the regular system and allow for monitoring and verification by HRA.

Well-directed and publicized enforcement actions by HRA can go a long way towards promoting a culture of compliance and sense of fairness and equity among all citizens. Failure by a growing number of small businesses on the other hand is likely to breed resentment among the taxpaying public and further drive down willful noncompliance. A well-designed system must align as far as possible the TOT system, which promotes to the regular tax system to facilitate transition and incentivize businesses that want to expand and make use of the opportunities presented in the formal sector. Attempts to broaden the tax base should build on insights into how citizens experience and perceive the tax administration and enforcement, and whether and how their tax behavior is correlated with their perceptions. HRA must invest in providing a stronger link between taxes and government expenditures and gather more systematic and coherent information on taxpayer attitudes towards tax policy design and implementation for better-informed tax policy design.

\subsection{Areas for Further Study}

Numerous studies suggest that there is more to the compliance game than simply administrative enforcement of taxes imposed on the unwilling. In various empirical studies, tax morale is shown to be a crucial determinant of taxpaying behavior. More research should be undertaken on tax morale among Ethiopi's informal sector to understand their motivations and reactions to perception of the behavior of the state and other taxpayers. Research suggests an inverse relationship between tax morale and belief about extent of tax evasion. A growing body of knowledge is emerging on nudging or behavioral psychology that is focused on influencing mass compliance behavior from a social perspective.

\section{Limitations of this Study}

Tax collection is affected by many factors outside the control of HRA such as political factors, socio-economic characteristics, and public perceptions about government expenditure and corruption, which are seldom well controlled for when evaluating impact of various measures. Hence, the use of tax efficiency measures based only on controllable outputs and inputs may distort the observed performance of HRA and lead to unreliable results.

\section{References}

[1] Ahmet, S. I. (2002). Shadow Economy in Bulgaria: Small and Medium Enterprises and Taxation.

[2] Barreca, D and S. Ramachandran (2004), Improving tax administration with data mining, Executive Report, TCWP0504, Elite Analytics, LLC, available at $<$ ftp://hqftp1.spss.com/pub/web/wp/TCWPlr.pdf>, accessed on February 2013.

[3] Baurer, L. I. (2005). Tax administrations and small and medium enterprises (SMEs) in developing countries, World Bank Group Bhartia, H. L. (2009). Public Finance. 14th Ed., Vikas Publishing House PVT Ltd, New Delhi.

[4] Brondolo, J. (2009). Collecting taxes during an economic crisis: challenges and policy options, International Monetary Fund, Fiscal Affairs Department.

[5] Chattopay, S. \& Arindam D. G. (2002). The compliance cost of the personal income tax determinant, National institute of Public Finance and Policy, New Delhi.

[6] Chigbu, E. E., Eze, A. L. and Ebimobowei, A. (2012). An empirical study on the causality between economic growth and taxation in Nigeria, Current Research Journal of Economic Theory, Vol. 4, No. 2, pp. 29-38.

[7] Chilipunde, R. L. and Shakantu, W. (2010). Constraints and challenges faced by small, medium and microenterprise contractors: a case study of Malawi, Department of Construction Management, Nelson Mandela Metropolitan University.

[8] Chiumya, C. (2006), Counteracting tax evasion in Malawi: An analysis of the methods and a quest for improvement, MPRA Paper No. 9892.

[9] Creswell, J. W., 2009. Research design: Qualitative, Quantitative, and Mixed Methods approaches. California: Sage Publications.

[10] Cochran, W. G., 1977. Sampling Techniques. 3rd Ed Ed. New York: John Wiley \& Sons.

[11] DAC (2008). Governance, taxation and accountability: issues and practices, OECD.

[12] Dodge, J. M. (2005). Theories of tax justice: ruminations on the benefit, partnership, and ability-to-pay principles, Florida State University, Public Law and Legal Theory, Working Paper No. 150.

[13] Fishlow, A. \& Friedman, J. (1994). Tax evasion, inflation and stabilization, Journal of Development Economics, Vol. 43, No. 1, pp. 105-123 Forum on Tax Administration (2009). Fifth meeting of the OECD forum on tax administration. FTA Communiqué, Paris.

[14] Freeman, H. A., Ellis, F. and Allison, E. (2003). Livelihoods and Rural Poverty Reduction in Kenya, LADDER Working Paper No 33, 2003. 
[15] Friedman, E. J., Kaufmann, D. \& Zoido-Lobaton, P. (2000). Dodging the grabbing hand: the determinants of unofficial activity in 69 countries, Journal of Public Economics, Vol. 76.

[16] Friedland, N., M. S., \& R. A. (1978). A simulation study of income tax evasion. Journal of Public Economics, 8.107-116.

[17] Eriksen, K., \& F. L. (1996). Tax knowledge and attitudes towards taxation areport on a quasi experiment. Journal of Economic Psychology, 387-402.

[18] Giles, D. A. E. and Tedds, L. M. (2002). Taxes and the Canadian Underground Economy. Canadian Tax Foundation.

[19] Gliem, J. A. and Gliem, R. R. (2003). Calculating, interpreting, and reporting Cronbach's Alpha reliability coefficient for Likert-Type scales, Midwest Research to Practice Conference in Adult, Continuing, and Community Education, retrieved on 10th December 2012 from https://scholarworks.iupui.edu/bitstream/handle/1805/344.

[20] Golab, J. (1996). How would a flat tax affect small businesses? Economic Review Federal Reserve Bank of Kansas City (U.S.); Vol. 81, No. 3: pp. 5-19.

[21] Government of Kenya. Income Tax Act, Cap 470, Government of Kenya.

[22] IFC (2000). The State of Small Business in Ukraine, IFC.

[23] IFC (2007). Designing a Tax System for Micro and Small Businesses: Guide for Practitioners, International Finance Corporation, Pennsylvania, Washington D.C.

[24] IMF (2008). Kenya: Selected Issues and Statistical Appendix. IMF, 2008. Report no. 08/200.

[25] International Tax Dialogue (2007). Taxation of small and medium enterprises, Background paper for the International Tax Dialogue Conference, Buenos Aires.

[26] Islahi, A. A. (2006). Ibn Khaldun's theory of taxation and its relevance today, Paper for presentation to the Conference on Ibn Khaldun, Madrid, SPAIN.

[27] Israel, G. D. (1992). Determining sample size. University of Florida Cooperative Extension Service, Institute of Food and Agriculture Sciences, EDIS.

[28] Kringi, S., Wanjala, B., Nyamunga, J., Okello, J. Pambah, E., \& Nyakang o, E. (2005). Tax reform experience in Kenya, KIPPRA Working Paper No. 13.

[29] Mankiw, G., Weinzierl, M., \& Yagan, D. (2009). Optimal Taxation in Theory and Practice, retrieved on 13th July 2012 from http://www.economics.harvard.edu.

[30] Mastrianna, F. V. (2009). Basic Economics, Mason, Ohio: Thompson South-Western.

[31] Memba S. F., Gakure W. R. and Karanja K. (2012). Venture capital (VC): its impact on growth of small and medium enterprises in Kenya, International Journal of Business and Social Science, Vol. 3, No. 6.

[32] Mugenda, O. M. \& Mugenda, A. G. (1999). Research Methods; Quantitative and Qualitative Approaches. Nairobi; Acts Press.
[33] Muriithi, M. K. and Moy, E. D. (2003). Tax reforms and revenue mobilization in Kenya, The African Economic Research Consortium: Nairobi.

[34] Ojeka, S. A. (2011). Tax Policy and the Growth of SMEs: Implications for the Nigerian Economy, Research Journal of Finance and Accounting, Vol. 2, No 2.

[35] Ouma, S., Njeru, J., Kamau, A., Khainga D., and Kiriga, B. (2007). Estimating the size of the underground economy in Kenya, KIPPRA Discussions Paper Series DP/82/2007

[36] Pashev, K. (2005). Corruption and tax compliance: challenges to tax policy and administration, Centre for the Study of Democracy, Sofia, Bulgaria.

[37] Rakner, L. and Gloppen, G. (2002). Tax reform and democratic accountability in Sub-Saharan Africa, IDS Bulletin, Vol. 33, No. 3.

[38] Sandford, C. (1995). Tax compliance costs: measurement and policy, Bath, UK: Fiscal Publications.

[39] Schneider, F. and Torgler, B. (2007). The Impact of Tax Morale and Institutional Quality on the Shadow Economy, Institute for the Study of Labor, Discussion Paper N ${ }^{\circ} 2541$, Bonn.

[40] Shapiro, J. (2005). U. K. Tax Law Changes and Impact on U.S. Taxpayers, Philadelphia Tax Conference.

[41] Siyimu, D. (2013). Challenge affecting collection of turnover tax in kenya. Nirobi.

[42] SMEDA (2007), Developing SME Policy in Pakistan, SMEDA.

[43] Southern and Eastern African Trade, Information and Negotiations Institute (2010). Towards taxation for development: challenges and opportunities; the case of Uganda, Southern and Eastern African Trade, Information and Negotiations Institute.

[44] Spiro, P. S. (2005). Size, Causes and Consequences of the Underground Economy, Ashgate Publishing, Aldershot, England.

[45] Stern, R. E. \& Barbour, P. A. (2005). Designing a small business tax system that enhances growth: lessons from Africa, World Bank Group.

[46] Wanjiku, L. W. (2009). An investigation into management strategies affecting performance of micro, small and medium enterprises (MSMES) in Kenya, Unpublished Thesis, University Of South Africa.

[47] Waweru, M. G. (2007). Addressing the different tax policy and tax administrative challenges of micro, small and medium businesses, A presentation at the International Tax Dialogue Global Conference From 17th - 19th October 2007 At Buenos Aires, Argentina.

[48] Weichenrieder, A. J. (2007). Survey on the taxation of small and medium-sized enterprises, OECD Centre for Entrepreneurship, SMEs \& Local Development (CFE).

[49] Webley, P., R. H., E. H., \& H. D. (1991). Tax Evasion. An Experimental Approach. Cambridge: Cambridge University Press. 